\title{
Correlates of Non-Partner Physical Violence among Ethiopian Women
}

\author{
Nasser B. Ebrahim
}

\section{check for}

updates

Citation: Ebrahim, N.B. Correlates of Non-Partner Physical Violence among Ethiopian Women. Societies 2021, 11, 68. https://doi.org/ $10.3390 /$ soc 11030068

Academic Editor: Gregor Wolbring

Received: 10 May 2021

Accepted: 25 June 2021

Published: 28 June 2021

Publisher's Note: MDPI stays neutral with regard to jurisdictional claims in published maps and institutional affiliations.

Copyright: (C) 2021 by the author. Licensee MDPI, Basel, Switzerland. This article is an open access article distributed under the terms and conditions of the Creative Commons Attribution (CC BY) license (https:// creativecommons.org/licenses/by/ $4.0 /)$.
Public Health, Keimyung University, Daegu 42601, Korea; nasser.ebrahim@gw.kmu.ac.kr

\begin{abstract}
Intimate and non-partner violence against women are major societal and public health problems afflicting many women around the world. Unlike intimate partner violence (IPV), nonpartner violence (NPV) has not been well researched in Ethiopia. Thus, individual, physical, social, and environmental factors associated with NPV are largely unknown. For the study, we used national data collected in the 2016 Ethiopia Demographic and Health Survey. The survey sample was selected with two-stage stratified cluster sampling. Multivariate logistic regression model was fitted to understand the association between NPV and its correlates. Overall, 45\% of the women reported having experienced physical NPV in Ethiopia. Women who owned assets, solely or jointly (land, house, or both), were 70\% less likely to report NPV than women who had no such assets. Thus, structural interventions that integrate women's asset ownership and provide special microfinancing services for women along with community-based gender education programs may have a potential to reduce violence against women in Ethiopia.
\end{abstract}

Keywords: Africa; Ethiopia; women; non-partner violence

\section{Introduction}

Violence against women, a gross violation of fundamental principles of human rights, is a major public health and societal problem, afflicting many women around the world [1]. Worldwide, 35\% of women have reported at some point experiencing sexual/physical violence by intimate partners or sexual violence by non-partners [2]. In 2017 alone, 87,000 women globally were intentionally murdered by their intimate partners or other family members. In the same year, 20,000 women were killed by family members other than their intimate partners [3]. Of all women killed by intimate partners or other family members in 2017; 20,000 of the deaths occurred in Asia, followed by 19,000 deaths in Africa. The lowest numbers were in Europe and Oceania, with 3000 and 300 homicides, respectively, of women by intimate partners or other family members [3].

Although violence against women can take many forms, interpersonal violence against women is generally categorized into intimate partner violence (IPV) or non-partner violence (NPV) [1]. The former is violence that occurs within the context of intimate relationships [4]; the latter is violence by other family members (parents, sons or daughters, siblings, other blood relatives, or affines) or by strangers or other persons familiar to the victims. Both forms of violence are linked to long-lasting and adverse health outcomes that can impact the health and wellbeing of women [1,5]. Owing to its pervasiveness across diverse human societies [3], IPV is the subject of the vast majority of research reports on violence against women from around the world [4,6-8]. Even though NPV is equally pernicious to women's health [1], it is less researched, especially in Africa $[9,10]$. The prevalence of non-partner sexual violence in Africa is estimated to be $12 \%$-the highest rate among low-and middle-income countries [1]. In Ethiopia, one in four (24.9\%) women reported having experienced physical violence by non-partners [11]. For example, simply accessing common household essentials such as water, sanitation, and family energy needs could expose women to NPV in Africa [12,13], as many women in the region often 
travel long distances to fetch water and firewood for their households, risking sexual or physical violence along the way $[12,14,15]$. Ethiopia is predominately an agrarian society with 80 percent of its population residing in rural areas. Although women make significant labor contributions to agricultural production, access to family resources and community participation is often limited. Furthermore, women also experience physical, sexual, or emotional violence [16]. For example, in 2019, Ethiopia was ranked 125th out of 162 countries in the Gender Inequality Index (GII), and in the years, 2015-2019, only 11.5\% of women had at least some secondary education, while the figure was $22.6 \%$ for men [17]. Ethiopia is a patriarchal society in which cultural values and practices undergird male dominance [18], and women still face significant inequities, including limited opportunities for development, education, and employment [19].

In general, violence against women stems from societal norms of acceptance of violence and unequal gender power relations [8] that are maintained by a system that is biased against women [20]. However, in Africa, including Ethiopia, factors associated with NPV are not fully understood, as research and information on NPV are limited $[9,10]$.

Addressing gender-based violence may also contribute toward achieving sustainable development goals [21]. Ecological models are often used to explain multiple determinants of violence against women [22]. Thus, identifying exposing and preventive factors could help develop a thorough understanding of NPV correlates in the Ethiopian context. Therefore, the purpose of this study is to identify individual, social, and environmental factors associated with women's experiences of physical non-partner violence in Ethiopia. We found no prior studies that specifically examined non-partner violence among Ethiopian women. The study, beyond filling a knowledge gap in this respect, may also contribute towards understanding and preventing violence against women.

\section{Methods}

\subsection{Sample Design}

For the current study, we used data collected in the 2016 Ethiopia Demographic and Health Survey (EDHS-2016). A two-stage stratified cluster sampling was used to select the survey sample. In the first stage, a total of 645 enumeration areas were selected (202 from urban areas and 443 from rural areas) by using the proportional probability sampling method. In the second stage, an equal probabilistic systematic selection was applied [11]. For the study, we used data from women $(n=378)$ between 15 and 49 years of age who gave responses to the non-partner physical violence question. The survey procedure and protocol were reviewed and approved by the Federal Democratic Republic of Ethiopia's Ministry of Science and Technology and the Institutional Review Board of ICF [11]. In collecting data about violence against women, safety recommendations of the World Health Organization were followed [11].

\subsection{Measurements}

\subsubsection{Explanatory Variables}

In ecological models, multiple factors are assumed to be the determinants of human health [18]. It is thus anticipated that non-partner physical violence is to be associated with the following factors: (1) individual-level factors (women's age, religious affiliation, household wealth, and behavioral factors such as women's alcohol use); (2) environmental factors that could expose women to non-partner violence, including physical environments such as residence type, access to drinking water on the premise, access to improved toilet facility, and access to cooking fuel; (3) environments protective against non-partner physical violence, including women's empowerment variables (education levels, employment status, and women's asset ownership) and access to communication and awareness. The coding of variables is shown in Table 1. 
Table 1. Variable description and categorization.

\begin{tabular}{|c|c|c|}
\hline Variable & Descriptions & Categories \\
\hline \multirow{2}{*}{\multicolumn{3}{|c|}{$\begin{array}{l}\text { Explanatory variables } \\
\text { Exposing Factors: Individual level }\end{array}$}} \\
\hline & & \\
\hline Women's age & Age in years & $15-24=0 ; 25-34=1,35-49=2$ \\
\hline Women's religious affiliation & Christians/Muslims/Traditional & Christian $=0 ;$ Muslims $/$ traditional $=1$ \\
\hline Household wealth & $\begin{array}{l}\text { wealth index (generated from household } \\
\text { income, consumption, and expenditures) }\end{array}$ & Poor $=0 ;$ middle $=1 ;$ rich $=2$ \\
\hline Women's alcohol use & $\begin{array}{c}\text { Have you ever taken a drink that } \\
\text { contains alcohol? }\end{array}$ & No $=0 ;$ Yes $=1$ \\
\hline \multicolumn{3}{|l|}{ Exposing factors: physical environments } \\
\hline Rural/urban & Place of residence & Rural $=0 ;$ urban $=1$ \\
\hline Access to drinking water $\dagger$ & Source of drinking water on the premise & No $=0 ;$ Yes = 1 \\
\hline Access to toilet facilities $\ddagger$ & Type of toilet facility & $\begin{array}{l}\text { No access to toilet facility }=0 ; \text { access to } \\
\text { toilet facility }=1\end{array}$ \\
\hline Access to improved cooking fuel ${ }^{*}$ & Type of cooking fuel & $\begin{array}{l}\text { No access to improved fuel }=0 ; \\
\text { Access to improved fuel }=1\end{array}$ \\
\hline \multicolumn{3}{|l|}{$\begin{array}{l}\text { Protective factors: women's } \\
\text { empowerment: social environment }\end{array}$} \\
\hline Educational level & Women's education & $\begin{array}{c}\text { No education }=0 \text {; primary }=1 \text {; secondary } \\
\text { and higher }=2\end{array}$ \\
\hline Employment status & Women's employment status & Unemployed $=0 ;$ employed $=1$ \\
\hline Women's asset ownership & $\begin{array}{l}\text { Women own house alone or jointly } \\
\text { Women own land alone or jointly }\end{array}$ & $\begin{array}{c}\text { Owns neither house nor land }=0 \\
\text { Owns land or house or both, alone or } \\
\text { jointly }=1\end{array}$ \\
\hline Media exposure & $\begin{array}{l}\text { Frequency of reading newspaper or } \\
\text { magazine } \\
\text { Frequency of listening to radio } \\
\text { Frequency of watching television }\end{array}$ & $\begin{array}{l}\text { No exposure }=0 \\
\text { any exposure }=1\end{array}$ \\
\hline Outcome variable & $\begin{array}{c}\text { Frequency of being hit in the last } 12 \\
\text { months by someone other than } \\
\text { husband/partner }\end{array}$ & Not at all $=0 ;$ often or sometimes $=1$ \\
\hline
\end{tabular}

+ Categories based on women who had access to drinking water on the premise and spent no time in accessing drinking water were categorized in the "yes" group and those who spent any time in accessing drinking water grouped as the "no" group. $\ddagger$ Access to flush toilets as well as various forms of pit latrines and other forms of human waste disposal facilities was grouped as "yes", as opposed to open field/bush defecation, categorized as "no". * Access to improved cooking fuel included electricity, natural gas, LPG, kerosene, biogas as opposed to fuel from wood, charcoal, crop residues, animal dung.

\subsubsection{Outcome Variable}

The outcome variable reflecting women's experiences of non-partner physical violence was captured by assessing women's responses to this question: What is the frequency of being hit in the last 12 months by someone other than your husband/partner? Multiplechoice responses to the question were: (a) not at all, (b) often, or (c) sometimes. Women who responded "not at all" were coded " 0 ", and those who answered "often" or "sometimes" were coded "1." See Table 1.

\subsection{Data Analysis}

Variables in the model were screened for multicollinearity. Variance inflation factors (VIF) showed no evidence of multicollinearity among variables (VIF range: 1.091-2.069). We analyzed the data by using the module for complex data analysis in SPSS v25.0. Domestic violence sampling weight was applied, and complex survey design effects arising from cluster and strata were accounted for. Bivariate associations were tested by chi-square statistics. In the multivariate analysis, we regressed the outcome variable on the explanatory variables using a logistic regression model. A $p$-value of less than 0.05 was used to determine statistical significance. 


\section{Results}

Overall, 44.7\% (95\% CI: 36.3-53.4) of the women reported having experienced nonpartner physical violence in the prior 12 months. One in 10 of the women $(11.4 \%$; 95\% CI 7.4-17.3) experienced non-partner physical violence "often", while one in three (33.2\%; 95\% CI 25.8-41.6) reported having experienced non-partner physical violence "sometimes" in the last 12 months. At the bivariate level, women's religious affiliations, women's access to improved cooking fuel, and women's asset ownership were significantly associated with women's experience of non-partner physical violence. Women's household wealth and alcohol use were marginally associated with non-partner physical violence at bivariate level (Table 2).

Table 2. Hypothesized exposing and protective factors in relation to non-partner physical violence among Ethiopian women.

\begin{tabular}{|c|c|c|c|c|}
\hline & \multicolumn{4}{|c|}{ Non-Partner Physical Violence } \\
\hline & \multicolumn{2}{|r|}{ No } & \multicolumn{2}{|l|}{ Yes } \\
\hline & Subtotal & $\mathbf{N}(\%)$ & N (\%) & $p$ \\
\hline \multicolumn{5}{|l|}{ Exposing Factors: Individual level } \\
\hline \multicolumn{5}{|l|}{ Age in years } \\
\hline $15-24$ & 139 & $67(47.9)$ & $72(52.1)$ & \\
\hline 25-34 & 129 & $78(60.5)$ & $51(39.5)$ & \\
\hline $35-49$ & 111 & 65 (58.6) & $46(41.4)$ & 0.332 \\
\hline \multicolumn{5}{|l|}{ Religious affiliation } \\
\hline Christians & 309 & $185(59.9)$ & $124(40.1)$ & \\
\hline Muslims/Traditional/others & 69 & $24(34.9)$ & $45(65.1)$ & 0.03 \\
\hline \multicolumn{5}{|l|}{ Household wealth } \\
\hline Poor & 99 & $44(44.3)$ & $55(55.7)$ & \\
\hline Middle & 53 & $39(74.5)$ & $14(25.5)$ & \\
\hline Rich & 226 & $126(55.7)$ & $100(44.3)$ & 0.052 \\
\hline \multicolumn{5}{|l|}{ Women alcohol use } \\
\hline No & 189 & $90(47.5)$ & $99(52.5)$ & 0.054 \\
\hline Yes & 190 & $120(63.1)$ & $70(36.9)$ & \\
\hline \multicolumn{5}{|c|}{ Exposing factors: Community/household level } \\
\hline Rural & 241 & $129(53.7)$ & $112(46.3)$ & \\
\hline Urban & 138 & $80(58.2)$ & $58(41.8)$ & 0.618 \\
\hline \multicolumn{5}{|c|}{ Access to drinking water source on the premise } \\
\hline No & 252 & $129(51.3)$ & $123(48.7)$ & \\
\hline Yes & 122 & $78(64.1)$ & 44 (35.9) & 0.136 \\
\hline \multicolumn{5}{|l|}{ Access to toilet facility } \\
\hline No & 94 & $57(60.5)$ & $37(39.5)$ & \\
\hline Yes & 281 & $156(54.3)$ & $131(45.7)$ & 0.613 \\
\hline \multicolumn{5}{|l|}{ Access to improved cooking fuel } \\
\hline No & 88 & $52(58.7)$ & $37(41.3)$ & \\
\hline Yes & 286 & $31(71.3)$ & $13(28.7)$ & 0.05 \\
\hline \multirow{2}{*}{\multicolumn{5}{|c|}{$\begin{array}{c}\text { Preventive factors: Women empowerment } \\
\text { Education }\end{array}$}} \\
\hline Education & & & & \\
\hline No education & 159 & $90(56.3)$ & $70(43.7)$ & \\
\hline Primary & 127 & $60(47.5)$ & $67(52.5)$ & \\
\hline Secondary+ & 92 & 59 (64.4) & $33(35.6)$ & 0.325 \\
\hline \multicolumn{5}{|l|}{ Employment } \\
\hline No & 211 & $107(50.8)$ & $104(49.2)$ & \\
\hline Yes & 167 & $102(61.1)$ & 65 (38.9) & 0.219 \\
\hline \multicolumn{5}{|l|}{ Women asset ownership } \\
\hline No & 198 & $91(45.6)$ & $108(54.4)$ & \\
\hline Yes & 179 & $119(66.1)$ & $61(33.9)$ & 0.007 \\
\hline \multicolumn{5}{|c|}{ Preventive factors: Communication and awareness } \\
\hline \multicolumn{5}{|l|}{ Media exposure } \\
\hline No & 153 & $81(52.7)$ & $73(47.3)$ & \\
\hline Yes & 225 & $129(57.1)$ & $96(42.9)$ & 0.605 \\
\hline Total & 375 & $\begin{array}{c}209(55.3) \\
\text { (95\% CI } 46.6 \text { to } 63.7)\end{array}$ & $\begin{array}{c}169(44.7 \%) \\
\text { (95\% CI } 36.3 \text { to } 53.4)\end{array}$ & \\
\hline
\end{tabular}

$p$ Probability of significant associations (Pearson's Chi-square); subtotals are different from the total count in cross-tabulation because cell counts have been rounded. Numbers are weighted.

In multivariate analysis, however, only women's household wealth and asset ownership associated significantly with women's experience of non-partner physical violence 
in the previous 12 months. As compared to women from poor households, women from middle-income households were $81 \%$ (OR $=0.189 ; 95 \%$ CI: $0.052-0.692)$ less likely to report non-partner physical violence. However, there was no significant difference between women from poor and rich households. Women who reported owning assets solely or jointly (land, house, or both) were $70 \%(\mathrm{OR}=0.299,95 \%$ CI: $0.149-0.600)$ less likely to have reported non-partner physical violence in the prior 12 months than women who had no such assets (Table 3).

Table 3. Adjusted odd-ratios (OR) and 95\% confidence (95\% CI) for non-partner physical violence by hypothesized exposing and protective factors.

\section{OR}

$95 \%$ CI

Exposing Factors: Individual level Age in years 15-24 25 $35-49$

Religious affiliation Christians

Muslims/Traditional/others

Household wealth

Poor

Middle

Rich

Women alcohol use

$$
\text { No }
$$

Yes

Exposing factors: Community/household level

Rural
Urban

Access to drinking water on the premise

$$
\text { No }
$$$$
\text { Yes }
$$

Access to toilet facility

$$
\text { No }
$$

Yes

Access to improved cooking fuel

$$
\begin{aligned}
& \text { No } \\
& \text { Yes }
\end{aligned}
$$

0.627

0.636

0.261-1.508

$0.232-1.739$

$$
1
$$

2.559

$0.906-7.226$

$$
1
$$

0.189 *

0.846

0.052-0.692

0.307-2.327

$$
1
$$

0.842

$0.402-1.764$

$$
1
$$

1.491

$0.425-5.230$

$$
1
$$

0.475

0.128-1.764

$$
1
$$

$0.471-3.214$

$$
1
$$

0.594

0.203-1.737

Protective factors: Women empowerment

$$
\text { Education }
$$

No education

Primary

1

1.124

0.506

$0.437-2.892$

Secondary+

Employment

$$
\text { No }
$$$$
\text { Yes }
$$

0.787

Women asset ownership

$$
\text { No }
$$$$
\text { Yes }
$$

0.299 *

Protective factor: Communication and awareness

Media exposure

$$
\text { No }
$$

Yes
1

0.941
0.365-1.697

0.149-0.600

0.137-1.865

0.435-2.040 


\section{Discussion}

Nearly $45 \%$ of women (aged 15-49) reported having experienced non-partner physical violence in the previous 12 months with $11.4 \%$ reporting having been hit often by a person other than their partner in the prior year. Estimates of comparable national non-partner physical violence among other African women are unavailable. However, prevalence of non-partner physical or sexual violence in 20 African countries varied between $2.3 \%$ and $11.3 \%$ [9]. In the neighboring country of Somalia, $16.5 \%$ of women reported having experienced physical or sexual violence in their adult lifetime [17]. For example, while a decreasing trend of intimate partner violence against women was observed in Italy [23], violence against women has increased across Africa [24]. Our findings suggest that nonpartner violence among Ethiopian women is a widespread phenomenon. Regardless of the perpetrators, violence against women can have multiple adverse health outcomes, including fatal, physical, sexual, psychological, or behavioral consequences [25]. The risk of violence against women is greatest in patriarchal societies like Ethiopia [26] where violence against women and others is tolerated and gender norms and inequities put women in a subordinate position [8,27].

In general, violence against women does not happen in a vacuum, but rather occurs in community contexts because harmful social norms can sustain gender-based violence [28]. Thus, community level prevention programs targeted at altering risky environments can be effective in reducing violence against women [29]. Threats and violence against women in the community or at home could impose an aura of fear and insecurity that can limit women's participation in economic, social, and political activities [29]. In addition, violence and harassment, place significant constraints on women's freedom of movement and access to resources [30]. Beliefs, traditions, and norms about gender relations in societies operate within communities and therefore are considered significant barriers, hindering women access to justice and protection from violence. Addressing these barriers is vital for community-level interventions to have a successful impact [29]. Changing community norms that sustain violence requires the engagement of the whole community. The first step is to create enabling environments that empower women to resist and challenge violence [30]. Collaborative community programs that provide opportunities for women to come together and develop their self-confidence, increase awareness, leadership skills, and build social support networks are thus essential [30].

In multivariate analysis, household wealth was significantly associated with physical NPV. Although women living in middle-income households were less likely to experience physical NPV than women from poorer households, there was no difference between women from poor and wealthy households, suggesting the relationship was not linear. It may be that poverty is related to stress, which may induce violence [8], and better resources among women may cause a backlash that could lead to more abuse [31]. Similar results of non-linear relationships of violence and wealth have been reported among diverse African women populations [32,33]. For example, Bamiwuye and Odimegwu [32], who analyzed data from several African women populations observed that women from rich households in Zambia and Mozambique were more likely to experience violence than women from poor and middle-income households. In Nigeria and Cameroun, women from middle-income households were more likely to experience violence than women from poor or rich households [32]. Research reports on poverty-wealth differences and non-partner violence are scant as most literature reports are based on intimate partner violence $[32,33]$ with inconsistent findings. For example, in India, women from richer households were reported to experience less physical and sexual violence [34]; however, a multi-country study showed that violence against women can transcend the economic divide and affect both poor and wealthy women alike [35].

Environmental factors that may expose women to NPV, such as access to drinking water, toilet facilities, and improved cooking fuel, were not associated with women experiencing non-partner physical violence. In other words, the odds of experiencing non-partner physical violence were not different between women who reported having those facilities 
on the premises and those who did not. In contrast, accessing common household essentials such as water, sanitation, and family energy needs in Africa has been reported to expose women to NPV [12,13].

However, women's asset ownership was associated with less experience of physical NPV among women. Women's asset ownership (land and/or house), solely or jointly, was associated with less likelihood of experiencing physical NPV. Grabe [36,37] showed that the mechanism through which women's asset ownership, particularly land ownership, could reduce violence against women. The author attributed female land ownership to the concomitant changes in cultural gender roles and power relationships in favor of women. For example, in India, women's land ownership was reported to have significantly reduced violence against women [38]. The authors ascribed the negative influence of women's land ownership to the associated and enhanced economic empowerment, social position, and awareness. In contrast, Pereira et al. [39], using a large sample of women from 28 countries, reported the relationship between asset ownership and intimate partner violence to be inconclusive. Ethiopia's new land reform, aimed at increasing land tenure security and women's rights to own land, has enabled the implementation and delivery of millions of land ownership certificates to women [40], although the impact of such structural change on violence against women is largely unknown. Nonetheless, in the Ethiopian context, our results may suggest that enhanced female asset ownership may have an important role to play in reducing violence against women and may have an implication in mitigating the impact of violence against women in Africa.

Women's access to assets and other resources, a reflection of women's autonomy and empowerment in society, often form part of integrated community intervention strategies to protect women against violence $[30,41]$. For example, in rural South Africa, microfinancing interventions that targeted the poorest women and provided participatory gender and HIV education in the community have been reported to reduce intimate partner violence by $55 \%$ [42]. In Ethiopia, the expansion and availability of microfinancing, especially to women, could play a vital role in creating a conducive environment for asset accumulation and improvement of the livelihoods of poor women. However, microfinancing institutions in Ethiopia currently have the capacity to meet only $20 \%$ of the financial demands of the poor [43]. Creating special microfinancing services for women [40] in tandem with community-based gender education programs may have the potential to reduce violence against women in Ethiopia. Girls' and women's education are instrumental to accessing remunerative jobs and financial resources, which, beyond improving women's status, could also contribute to overall economic development and gender equity in Ethiopia [44]; thus, community advocacy for increased investment in girls' and women's education may be warranted.

\section{Conclusions}

NPV, like IPV, is a widespread phenomenon in Ethiopia. Nearly $45 \%$ of women reported having experienced non-partner physical violence in the last 12 months. Women's asset ownership (land, house, or both), solely or jointly, was associated with less nonpartner physical violence. Thus, structural interventions that integrate women's asset ownership and provide special microfinancing services for women, along with communitybased gender education programs, may have the potential to reduce violence against women in Ethiopia.

Funding: This research received no external funding.

Institutional Review Board Statement: The project complies with all of the requirements of 45 CFR 46, Protection of Human Subjects. 132989.0.000.ET.DHS.01.

Informed Consent Statement: Informed consent was obtained from all subjects involved in the study.

Data Availability Statement: Data is owned by Demgraphic and Health Survey. https: / dhsprogram. com/, accessed on 8 January 2021. 
Conflicts of Interest: The author declares no conflict of interest.

\section{References}

1. World Health Organization. Global and Regional Estimates of Violence against Women: Prevalence and Health Effects of Intimate Partner Violence and Non-Partner Sexual Violence. World Health Organization. 2013. Available online: https: / /apps.who.int/iris/bitstream/handle/10665/85239/9789241564625_eng.pdf (accessed on 15 March 2021).

2. UNWOMEN. Facts and Figures: Ending Violence against Women. 2019. Available online: https://www.unwomen.org/en/whatwe-do/ending-violence-against-women/facts-and-figures (accessed on 2 March 2021).

3. United Nations Office on Drugs and Crime Global Study on Homicide Gender-Related Killing of Women and Girls. 2019. Available online: https:/ / www.unodc.org/documents/data-and-analysis/gsh/Booklet_5.pdf (accessed on 20 January 2021).

4. World Health Organization (WHO). Understanding and Addressing Violence against Women. 2012. Available online: http:/ / apps.who.int/iris/bitstream/handle/10665/77432/WHO_RHR_12.36_eng.pdf;jsessionid=C0B1C8194D2FC0450532 BED4D6783411? sequence $=1$ (accessed on 12 February 2021).

5. Campbell, J.C. Health consequences of intimate partner violence. Lancet 2002, 359, 1331-1336. [CrossRef]

6. Devries, K.M.; Mak, J.Y.; Garcia-Moreno, C.; Petzold, M.; Child, J.C.; Falder, G.; Pallitto, C. The global prevalence of intimate partner violence against women. Science 2013, 340, 1527-1528. [CrossRef] [PubMed]

7. Garcia-Moreno, C.; Jansen, H.A.; Ellsberg, M.; Heise, L.; Watts, C.H. Prevalence of intimate partner violence: Findings from the WHO multi-country study on women's health and domestic violence. Lancet 2006, 368, 1260-1269. [CrossRef]

8. Jewkes, R. Intimate partner violence: Causes and prevention. Lancet 2002, 359, 1423-1429. [CrossRef]

9. Barchi, F.; Winter, S.C. Non-partner violence in Sub-Saharan Africa and the built environment: A multicountry analysis of the effects of sanitation, water access, and urban settings. Violence Women 2020, 26, 1101-1119. [CrossRef] [PubMed]

10. Muluneh, M.D.; Stulz, V.; Francis, L.; Agho, K. Gender based violence against women in sub-Saharan Africa: A systematic review and meta-analysis of cross-sectional studies. Int. J. Environ. Res. Public Health 2020, 17, 903. [CrossRef] [PubMed]

11. Central Statistical Agency (CSA) [Ethiopia]; ICF International. Ethiopia Demographic and Health Survey. Addis Ababa, Ethiopia, and Rockville, Maryland, USA: CSA and ICF International. 2017. Available online: https://dhsprogram.com/pubs/pdf/FR328 /FR328.pdf (accessed on 8 January 2021).

12. Sommer, M.; Ferron, S.; Cavill, S.; House, S. Violence, gender and WASH: Spurring action on a complex, under-documented and sensitive topic. Environ. Urban 2015, 27, 105-116. [CrossRef]

13. Sorenson, S.B.; Morssink, C.; Campos, P.A. Safe access to safe water in low income countries: Water fetching in current times. Soc. Sci. Med. 2011, 72, 1522-1526. [CrossRef] [PubMed]

14. Massey, K. Insecurity and Shame: Exploration of the Impact of the Lack of Sanitation on Women in the Slums of Kampala, Uganda. Sanitation and Hygiene Applied Research for Equity. 2011. Available online: https:/ /assets.publishing.service.gov.uk/ media/57a08ae9e5274a27b2000839/VAW_Uganda.pdf (accessed on 12 January 2021).

15. Safe Access to Fuel and Energy [SAFE]. Available online: https://www.safefuelandenergy.org/issues/protection-gender.cfm (accessed on 27 February 2021).

16. United States Agency for International Development (USAID). Gender Equality and Women's Empowerment. 2020. Available online: https: / / www.usaid.gov / ethiopia / gender-equality-and-womens-empowerment (accessed on 13 June 2021).

17. United Nations Development Program: Human Development Report. Available online: http://hdr.undp.org/en/content/ gender-inequality-index-gii (accessed on 13 June 2021).

18. UK Essays. The Inequalities of Gender in Ethiopia. 2018. Available online: https://www.ukessays.com/essays/sociology/theinequalities-of-gender-in-ethiopia-sociology-essay.php?vref=1 (accessed on 13 June 2021).

19. United Nations Women (UN Women). Advancing Gender Equality: Promising Practices. Ethiopia no Leave Behind. Available online: https:/ /www.unwomen.org/mdgf/B/Ethiopia_B.html (accessed on 13 June 2021).

20. Montesanti, S.R.; Thurston, W.E. Mapping the role of structural and interpersonal violence in the lives of women: Implications for public health interventions and policy. BMC Women's Health 2015, 15, 100. [CrossRef] [PubMed]

21. Wirtz, A.L.; Perrin, N.A.; Desgroppes, A.; Phipps, V.; Abdi, A.A.; Ross, B.; Kaburu, F.; Kajue, I.; Kutto, E.; Taniguchi, E.; et al. Lifetime prevalence, correlates and health consequences of gender-based violence victimisation and perpetration among men and women in Somalia. BMJ Glob. Health 2018, 3. [CrossRef] [PubMed]

22. World Health Organization. The Ecological Framework. 2020. Available online: https://www.who.int/violenceprevention/ approach/ecology/en/ (accessed on 15 April 2021).

23. Nittari, G.; Sagaro, G.G.; Feola, A.; Scipioni, M.; Ricci, G.; Sirignano, A. First Surveillance of Violence against Women during COVID-19 Lockdown: Experience from “Niguarda” Hospital in Milan, Italy. Int. J. Environ. Res. Public Health 2021, $18,3801$. [CrossRef] [PubMed]

24. Deutsche Welle (DW). Violence against Women: Africa's Shadow Pandemic. Available online: https://www.dw.com/en/africapandemic-violence-rape-women/a-55174136 (accessed on 30 May 2021).

25. Perrin, N.; Marsh, M.; Clough, A.; Desgroppes, A.; Phanuel, C.Y.; Abdi, A.; Kaburu, F.; Heitmann, S.; Yamashina, M.; Ross, B.; et al. Social norms and beliefs about gender based violence scale: A measure for use with gender based violence prevention programs in low-resource and humanitarian settings. Confl. Health 2019, 13, 6. [CrossRef] [PubMed] 
26. Bott, S.; Morrison, A.; Ellsberg, M. Preventing and Responding to Gender-Based Violence in Middle and Low-Income Countries: A Global Review and Analysis; The World Bank: Washington, DC, USA, 2005; Available online: https:/ /openknowledge.worldbank.org/ handle/10986/8210 (accessed on 12 April 2021).

27. Swedish International Development Cooperation Agency [SIDA]. A Profile on Gender Relations: Towards Gender Equality in Ethiopia. 2003. Available online: https://www.sida.se/contentassets/54d269b9567243f0861deacae205859a/towards-genderequality-in-ethiopia_470.pdf (accessed on 30 March 2021).

28. Centers for Disease Control and Prevention. Violence Prevention. 2019. Available online: https://www.cdc.gov/ violenceprevention/intimatepartnerviolence/riskprotectivefactors.html (accessed on 16 March 2021).

29. Department for International Development (DFID). How to Note. A DFID Practice Paper. 2012. Available online: https://assets.publishing.service.gov.uk/government/uploads/system/uploads/attachment_data/file/67335/How-tonote-VAWG-2-community-prog.pdf (accessed on 26 April 2021).

30. Fourth World Conference on Women. United Nations Division for the Advancement of Women, Department of Economic and Social Affairs. Available online: http://www.un.org/womenwatch/daw/beijing/platform/violence.htm (accessed on 30 May 2021).

31. True, J. The Political Economy of Violence against Women; Oxford University Press: Oxford, UK, 2012.

32. Bamiwuye, S.O.; Odimegwu, C. Spousal violence in sub-Saharan Africa: Does household poverty-wealth matter? Reprod. Health 2014, 11, 45. [CrossRef] [PubMed]

33. Cools, S.; Kotsadam, A. Resources and intimate partner violence in Sub-Saharan Africa. World Dev. 2017, 95, 211-230. [CrossRef]

34. Rashada, A.S.; Sharaf, M.F. Income Inequality and Intimate Partner Violence against Women: Evidence from INDIA; No. 222; Frankfurt School-Working Paper Series; Frankfurt School of Finance and Management: Frankfurt am Main, Germany, 2016.

35. Kishor, S.; Johnson, K. Women at the Nexus of Poverty and Violence: How Unique Is Their Disadvantage? Focus Gend. 2005, 147. Available online: https:/ / dhsprogram.com/pubs/pdf/od32/8.pdf (accessed on 20 March 2021).

36. Grabe, S. Promoting gender equality: The role of ideology, power, and control in the link between land ownership and violence in Nicaragua. ASAP 2010, 10, 146-170. [CrossRef]

37. Grabe, S. An empirical examination of women's empowerment and transformative change in the context of international development. Am. J. Community Psychol. 2010, 49, 233-245. [CrossRef] [PubMed]

38. Kelkar, G.; Gaikwad, S.; Mandal, S. Women's Asset Ownership and Reduction in Gender Based Violence. Landesa Heinrich Böll Found. 2015. Available online: https:/ / in.boell.org/sites/default/files/womens_asset_ownership_and_reduction_in_gender_based_ violence.pdf (accessed on 25 June 2021).

39. Pereira, A.; Peterman, A.; Yount, K. Exploring Women's Empowerment through Asset Ownership and Experience of Intimate Partner Violence; United Nations Children's Fund: New York, NY, USA, 2017.

40. Holden, S.; Tefera, T. Land Registration in Ethiopia: Early Impacts on Women. 2008. Available online: https://unhabitat.org/sites/ default/files/download-manager-files/Land\%20Registration\%20in\%20Ethiopia\%20Early\%20Impacts\%20on\%20Women.pdf (accessed on 25 March 2021).

41. Preventing Violence and Reducing Its Impact: How Development Agencies Can Help. Available online: https:/ /apps.who.int/ iris/bitstream/handle/10665/43876/9789241596589_eng.pdf (accessed on 25 April 2021).

42. Pronyk, P.M.; Hargreaves, J.R.; Kim, J.C.; Morison, L.A.; Phetla, G.; Watts, C.; Busza, J.; Porter, J.D. Effect of a structural intervention for the prevention of intimate-partner violence and HIV in rural South Africa: A cluster randomised trial. Lancet 2006, 368, 1973-1983. [CrossRef]

43. Morka, E.M.; Wamat, J. Ethiopian Microfinance Assessment Report: A Case for Entrepreneurship Skills Development for Youth in Sheep Fattening. 2020 Working Paper. ICARDA. Available online: https: / www.google.com/url?sa=t\&rct=j\&q=\&esrc= s\&source=web\&cd=\&ved=2ahUKEwiiuda527nxAhXKh_0HHaLqCV4QFjAAegQIAxAD\&url=https\%3A\%2F\%2Fmel.cgiar. org\%2Freporting\%2Fdownload\%2Fhash\%2F1afc31fd507df54af230b0c417dc30bd\&usg=AOvVaw3w YvuOh4yauxhr5Xuv3k-5 (accessed on 27 April 2021).

44. UNICEF Fact Sheet -Girl's Education. 2018. Available online: https://www.unicef.org/ethiopia/media/381/file/Girls\%20 Education\%20Advocacy\%20Brief\%20in\%20Ethiopia\%20.pdf (accessed on 27 April 2021). 